\title{
AUTONOMIC NERVOUS SYSTEM PROPERTIES IN MIGRAINE PATIENTS AND NONMEDICATION TREATMENT IN HEADACHE FREE PERIOD
}

\author{
Daina Voita*,**, Evita Vaḷēviča*, Anastasija Zakke*, Juris Porozovs**, \\ and Anda Kauliṇa** \\ * Latvian University Institute of Cardiology, Pilsoṇu iela 13, Rĩga, LV-1002, LATVIA \\ E-mail: dvoita@mits.Iv \\ ** Rīga Teachers Training and Educational Management Academy, Imantas 7. lìnija 1, Rīga, LV-1083, LATVIA
}

Communicated by Andrejs Ërglis

The aim of the study was to characterise parameters of the autonomic nervous system in migraineurs and to find out and to adapt the optimal biofeedback (BFB) training methods. Heart rate $(H R)$, arterial blood pressure and baroreflex sensitivity (BRS) at rest, static workload, arterial occlusion and during recovery period were measured. 22 migraineurs (female, average age $22.2 \pm$ 2.4 years) and 14 healthy age and gender matched controls participated. Migraine patients were divided into two groups (M1 and M2) according to HR and BRS at rest. At rest $60 \%$ of migraine patients (group M1) had significantly decreased HR vs. control group $(\mathrm{P}<0.01)$. The M2 group showed a tendency to decreased BRS at rest comparing to the control group and significantly $(\mathrm{P}<0.01)$ differed in this parameter from the $M 1$ group. In a $10 \mathrm{~s}$ precontraction period M1 group had a significantly lower HR increase comparing to other analysed groups $(\mathrm{P}<0.01)$. HR was significantly decreased in the M1 group during the recovery period comparing to the control and M2 groups ( $\mathrm{P}<0.05)$. Both parts of autonomic nervous system, PNS and SNS branches, were impaired in migraineurs. The M2 group had most likely decreased PNS activity and impaired SNS activity. M1 group patients showed increased PNS activity. BFB training sessions reduced migraine attack frequency and need for medication in the M2 group.

Key words: migraine, autonomic nervous system, biofeedback, handgrip.

\section{INTRODUCTION}

Psychological factors that influence pain experience are numerous and can include mood, anxiety, thought processes, personal coping mechanisms, social support, and personality factors, for example stress tolerance (Mc Guire et al., 2008). Migraine is a highly prevalent disease affecting individuals, their families, and economies across the world (Lipton et al., 2003). The highest prevalence rates have been reported in North America, where 18\% of women and $7 \%$ of men experience one or more migraine attacks per year (Lipton et al., 2001), but figures from Europe are similar (Stovner et al., 2006).

Migraine is a chronic neurological syndrome characterised by recurrent headaches and associated symptoms (nausea, vomiting, etc.) lasting from 4 to 72 hours (Anonymous, 2004; Olesen, 2005). Extensive research of the underlying pathophysiological mechanisms of migraine headaches based on the above-mentioned symptomatic features would favour a better understanding of the abnormalities and, thus contribute to the improvement of life-quality of mi- graineurs. The knowledge gained would enable to select the most appropriate and effective medical treatment as well as utilize alternative non-medically oriented techniques alongside with the pharmacologically oriented methods, for example, self-regulating biofeedback mechanisms (relaxation trainings etc.)

The studies regarding the function of autonomic nervous system (ANS) of migraineurs are inconclusive. Both hyperfunction (Yakinci et al., 1999) and hypofunction (Peroutka, 2004) of sympathetic nervous system (SNS) activity have been reported. Similarly, data on the function of the parasympathetic nervous system (PNS) are inconsistent: the evidence of several studies investigating clinical features and mechanisms of headache supports a decreased PNS activity (Sanya et al., 2005), whereas a number of other studies show an increased PNS activity (Yakinci et al., 1999; Yarnitsky et al., 2003; Avnon et al., 2004).

In contrast, the study conducted by Pierangeli et al. (1997) reported no changes in variables of heart rate (HR) and arterial diastolic blood pressure ( $\mathrm{dBP}$ ) in migraineurs in com- 
parison with controls assessed by Valsalva manoeuvre and orthostatic tests. The results reported by Cortelli et al. (1991) were similar. Although the findings provide no significant disturbances in ANS, increased heart rate (HR) variables at rest and comparatively greater increase in arterial blood pressure (ABP) in migraineurs in comparison with controls, implicated non-specific SNS hyperactivity.

In our study, we utilized a similar methodology to assess the features of ANS function in migraineurs in comparison with controls.

In many clinics all over the world, non-medical treatment is considered as an alternative or an addition methodology to pharmacological treatment for the reduction of frequency and severity of migraine attacks. One of these approaches is the biofeedback method (BFB) (Nestoriuc and Martin, 2007; Kabbouche and Gilman, 2008) used in our study.

The aim of the study was to determine the parameters of ANS in migraineurs and to find out and adapt the optimal BFB training.

\section{MATERIALS AND METHODS}

Participants. Data from 22 migraine patients (female, aged $18-25$, average $22.2 \pm 2.4$ years) and 14 healthy, nontrained age and sex matched control group persons without any other diseases were analysed. All medications, if any, had been discontinued at least 1 week before the study. The migraine patients were divided in two groups (M1 and M2) according to HR and baroreceptor reflex sensitivity (BRS) at rest. We suggested that these groups would differ in ANS function.

Procedure. Subjects were tested in supine position in a quiet room after a 10-min adaptation period. HR, ABP and BRS were recorded continuously during physical rest, precontraction orientation reaction (10 s period), static muscular effort (handgrip), and afterwork arterial occlusion (AO) on loaded extremity and recovery period by Task Force Monitor device (CNSystems Medizintechnik, Austria). Handgrip (HG) was performed with $50 \%$ of maximal voluntary contraction force (MVC) by dominant arm comfortably fixed on the support. The MVC was determined by applying a hydraulic dynamometer system securing optimal visual feedback control. MVC was measured as the mean force obtained in two maximal contractions separated by at least two minutes. HG with force $50 \%$ of MVC was performed for $60 \mathrm{~s}$ after $10 \mathrm{~s}$ of precontraction. During the last $5 \mathrm{~s}$ of $\mathrm{HG}$, a pneumatic cuff was inflated at $250 \mathrm{~mm} / \mathrm{Hg}$ on the upper arm of loaded extremity to arrest the circulation. Pressor reaction $(\mathrm{PR})$ level during post exercise occlusion is associated with activation of chemically and mechanically sensitive afferents (III and IV group) in contracting skeletal muscle (Mark et al., 1985). Non-invasive spontaneous baroreflex sensitivity sequence method was a measure to BRS (Bertinieri et al., 1985, Parati et al., 1988) The recovery period was ten minutes.
Biofeedback 2000 X-pert device (Schuhfried GmbH, Austria) was used for BFB training. Blood volume pulse amplitude (PVA) training of a. temporalis was used with the aim to optimise ANS function and reduce PVA measurement of the difference between the highest and lowest values of the blood volume pulse (BVP) relative to the maximum recordable range. A reflex pulse sensor was attached to the patient temple to receive PVA of $a$. temporalis. The sensor consists of an infra-red light source and an infra-red receiver. The infra-red light source operates at constant intensity. The pulsating change in blood flow causes fluctuations in the brightness of the reflected or transmitted light. These fluctuations are filtered out, amplified, and displayed as the BVP parameter. Visual biofeedback was maintained on a computer monitor during the entire session to ensure patient control of PVA. One session lasted for 20-30 minutes during which time the patient was asked to maintain reduced PVA as long as possible. Patients attended trainings 2-3 times a week. Migraine drug usage, pain frequency and intensity were recorded before and during biofeedback training sessions.

Statistical analysis of data. Data are presented as mean \pm standard deviation (SD). Analysis of variance (ANOVA) and paired Student t-tests were performed to indicate significant differences $(P<0.05)$.

The study was approved by the Ethics Committee of the University of Latvia Institute of Cardiology for clinical and physiological research, and pharmaceutical product clinical investigations.

\section{RESULTS}

At rest $60 \%$ of all migraine patients (group M1) had significantly decreased HR compared to the control group (61.9 \pm 5.6 beats/min vs. $77.1 \pm 4.9 ; P<0.01$ ) (Fig. 1 ). There were no statistically significant differences in HR between the M2 and control groups $(78.8 \pm 8.4$ vs. $77.1 \pm 4.9$ beats $/ \mathrm{min}$; NS). During the $10 \mathrm{~s}$ precontraction period (orientation reaction), the M2 group showed a tendency toward HR increase in comparison with other analysed groups $(91.0 \pm 3.6$ vs. $70.7 \pm 6.3$ vs. $81.2 \pm 6.8$ beats $/ \mathrm{min} P<0.01$ ), while the M1 group had a significantly lower HR than the control group. No statistical differences were found in the increase of HR during HG between analysed groups. The M1 group had a significantly lower HR comparing to the M2 group $(64.1 \pm 6.1$ vs. $79.7 \pm 8.5$ beats $/ \mathrm{min} ; P>0.01)$ during AO. HR was significantly decreased in the M1 group compared to the control and $\mathrm{M} 2$ groups $(61.6 \pm 5.9$ vs. $76.0 \pm 6.2$ vs. $74.5 \pm 9.5$ beats $/ \mathrm{min} ; P>0.01)$ during the recovery period.

Significant differences in systolic blood pressure (sBP) were found in the M2 group compared with control and M1 groups $(123.9 \pm 3.9$ vs. $109.4 \pm 5.1$ vs. $109.3 \pm 1.8 \mathrm{mmHg}$; $P<0.01$ ) at rest (Fig. 2). At the end of static workload, sBP increase showed a trend $(P>0.05)$ toward significance in the M2 group in comparison with control and M1 groups 

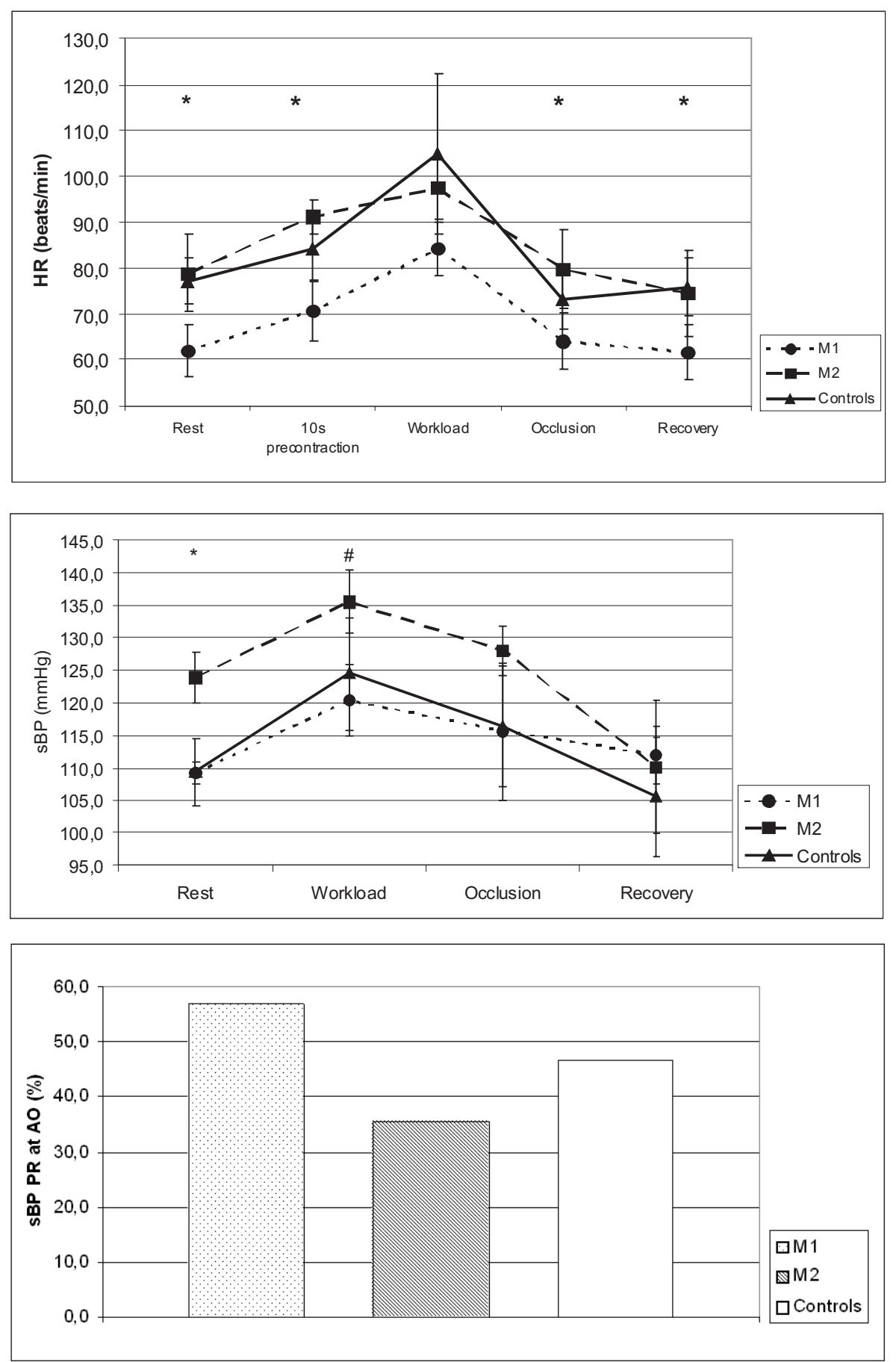

Fig. 1. Heart rate (HR) dynamics during the test in migraine and control group.

Fig. 2. Systolic blood pressure (sBP) dynamics during the test in migraine and control groups
Fig. 3. sBP pressor reaction (PR) during after-load arterial occlusion (AO) (\%) relative to that at static muscular effort reached PR.
$(135.5 \pm 4.8 \mathrm{mmHg}$ vs. $124.5 \pm 8.6 \mathrm{mmHg}$ vs. $120.4 \pm 5.5$ mmHg; $P>0.05)$.

There were no significant differences in diastolic blood pressure (dBP) dynamics in the analysed groups.

Regarding sBP dynamics (Fig. 3) during after-load AO, the M2 group had retained $35.6 \%$ of PR reached at the end of static muscular effort, while controls retained $46.5 \%$ and M1 retained $56.7 \%$.

Using spontaneous baroreflex sensitivity sequence method M2 group showed a significantly $(P<0.01)$ decreased BRS at rest comparing to control group $(9.5 \pm 2.3$ vs. $15.0 \pm 3.4$ $\mathrm{ms} / \mathrm{mmHg})$ and significant $(P<0.01)$ difference comparing to $\mathrm{M} 1$ group $(9.5 \pm 2.3$ vs. $29.7 \pm 10.1 \mathrm{~ms} / \mathrm{mmHg})$ (Fig. 4$)$.

Before training and during the biofeedback training process migraine patients were asked to complete migraine diary. Migraine patients used medication (Sumatriptan 50-100 $\mathrm{mg}$ ) during migraine attacks. For pain severity assessment visual analogue pain scale was used. It was found that PVA training for $a$. temporalis significantly decreased medication use in the M2 group compared to the period before nonmedical treatment (Fig. 5). Also, an insignificant trend of decreased pain intensity and migraine attack frequency (Fig. 6) in the biofeedback period was observed. These trends were not seen in the M1 group. 

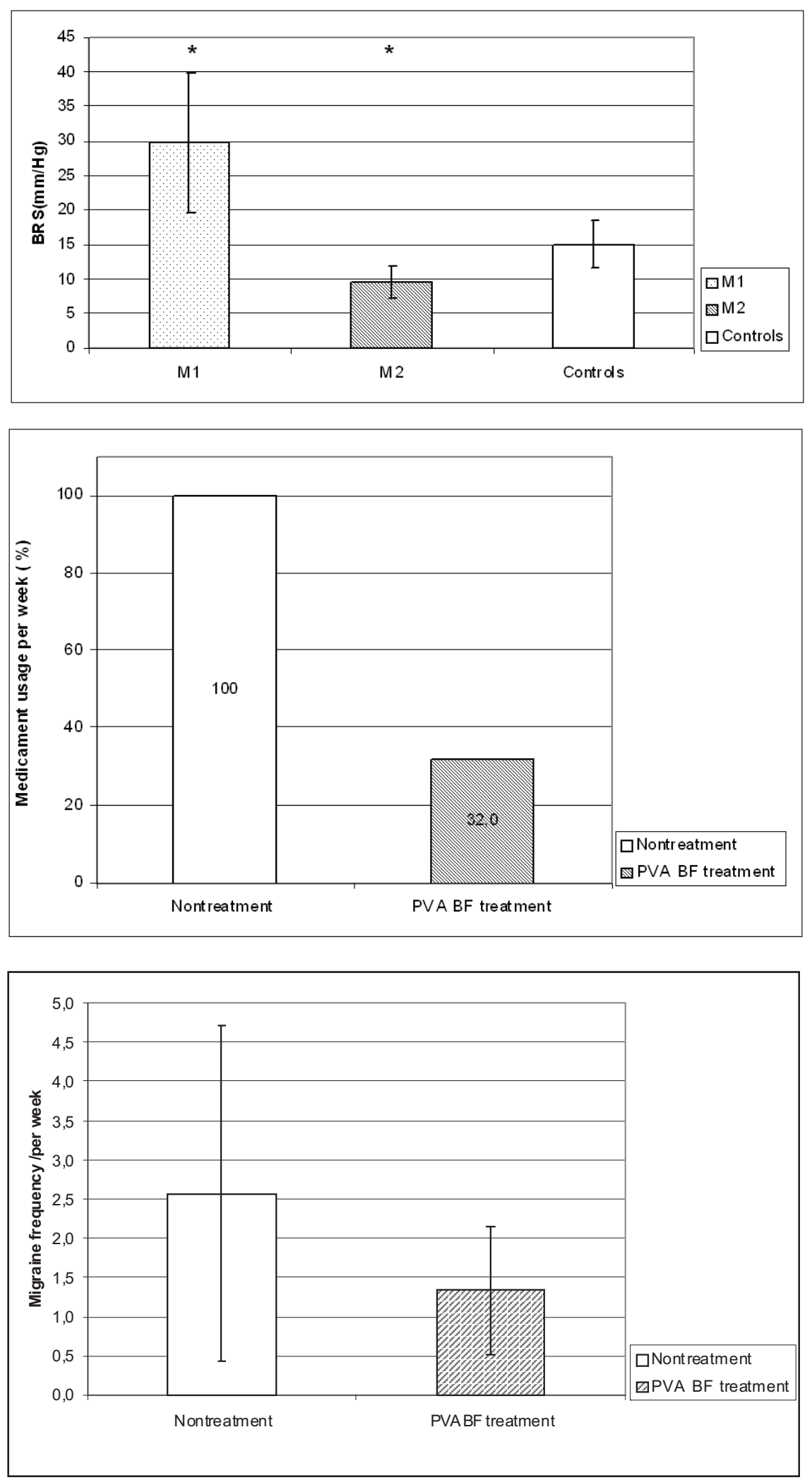

Fig. 4. Baroreflex sensitivity (BRS) at physical rest in migraine and control groups.

Fig. 5. Medication use (\%) per week in M2 patient group during nontreatment period and during biofeedback (BFT) treatment.

\section{DISCUSSION}

The obtained results agree with previous studies regarding HR at rest in the control group (Agelink et al., 2001). There were no significant differences in HR between the M2 group and controls at relative physical rest. In contrast, significantly lower HR was detected in M1 group, which might be related with increased PNS activity. This was confirmed also by BRS analysis. The observed significant increase in sBP and unchanged dBP variables might be related with inhibition of PNS activity in M2 group patients. However, in some studies an opposite effect was found, such as, decreased sBP (Gudmundsson et al., 2006) and increased dBP (Shechter et al., 2002) at rest. These discrepancies may be associated with different ANS activity properties of migraine patients. 
The BRS data in the control group were similar to those in other studies (Kardos et al., 2001). A changed sympathovagal balance in both M1 and M2 patient groups was shown by a significantly increased BRS in the M1 group and decreased BRS in the M2 group in comparison with controls. In studies using the spontaneous sequence method as in our investigation, BRS was increased in migraineurs in comparison with the control group at rest (Nilsen et al., 2009). We determined BRS only at relative physical rest due to methodical restrictions.

The orientation reaction in thee-load period also showed significant PNS inhibition in the M2 group in comparison with controls. This was supported by a significant HR increase even before the onset of the HG. This might be related with decreased stress tolerance in M2 group patients. In contrast, the M1 group showed a lower HR increase comparing to the M2 group during preload orientation reaction. There is insufficient data in the literature regarding orientation feedback in migraine patients.

The decreased HR increase at the end of HG in M2 group might be associated with already inhibited PNS activity in pre-load period. Only some studies have considered HG in regard to ANS function detection in migraineurs. In one of these studies, where a $30 \%$ MVC muscle contraction force was used, a significantly decreased HR increment during HG was stated, which was associated with sympathetic hypofunction (Pogacnik et al., 1993). No substantial differences were found in dBP dynamics in our study, whereas different results were presented in above mentioned study at static load. Authors reported a tendency toward a lower dBP increase and its absolute value compared with the value at rest was decreased. In a study on common migraine and migraine with panic attacks, a lower increase of dBP during HG with $30 \%$ MVC was observed in both migraine groups (Osipova, 1992). It was also shown that the mean blood pressure increase at the end of HG with $30 \%$ MVC was decreased due to SNS hypofunction (Mosek et al., 1999). This was supported by other study, where a difference in ABP increase during static load (HG) between migraine patients and controls was found. The migraine group showed a significantly lower ABP increase during $\mathrm{HG}$ with $50 \%$ MVC indicating SNS dysfunction (Benjelloun et al., 2005).

Also, it should be mentioned that different age migraine patients participated in above studies (Pogacnik et al., 1993; Mosek et al., 1999). Thus, the difference with our study group might be associated with different age groups involved.

The sBP increase was higher in controls compared to the M2 and M1 groups during HG. After load AO which is associated with activation of III-IV group afferents by metabolites in the loaded extremity the remaining increase was smaller in the M2 group compared to the control and M1 groups. This could be explained by a decrease of PNS inhibition by central command, PNS function normalisation or by re-establishing ANS balance, suggesting that the sympathetic part of ANS is also impaired in the M2 group. Pressor reaction during $\mathrm{AO}$ did not differ significantly between the M1 and control group. During the recovery period, HR and
sBP decreased below the baseline level in the M2 group, suggesting inhibition of PNS function in the pre-load period and lowered stress tolerance.

The obtained data on function of ANS in migraineurs suggests about impairment of both parts of ANS activity. There was most likely impairment in both branches of the ANS in the M2 group, with decreased PNS activity and impaired SNS activity, but M1 group patients showed increased PNS activity.

Sympatho-parasympathetic balance in migraine patients can be improved using the BFB training method (Herman and Blanchard, 2002; Scharff et al., 2002; Blanchard and Kim, 2005; Martin et al., 2007; Nestoriuc and Martin, 2007; Kabbouche and Gilman, 2008; Nestoriuc et al., 2008). The migraineurs were trained using the BFB training method, with the aim to estimate the efficacy and to elaborate an optimal training regimen. The most used and effective training methods for migraine therapies are temperature training and PVA training (Herman and Blanchard, 2002). It should be mentioned that PVA measurements within a single biofeedback session are highly reliable (Speckenbach and Gerber, 1999). We preferred to use PVA training due to its proven efficacy showed in previous investigations (Lisspers and Ost, 1990; Blanchard and Kim, 2005).

In BFB training sessions, female migraineurs aged 18-25 years participated. We did not find any literature regarding training of migraineurs in this age group which also considered ANS function.

The optimal training period when method provides effect was six weeks for each person in the M2 group with training session duration at least $20 \mathrm{~min}$ and 2-3 times weekly. It was suggested that founded relaxation training methodology which include 2-3 sessions weekly for 1-1.5 months was optimal for improving of ANS function in migraine patients with decreased stress tolerance. It was also shown that PVA training was the most suitable and effective method in comparison with other methods recommended for non medication migraine treatment, such as EMG and temperature trainings for M2 group suggested by reduced frequency of migraine attacks as well as less medication-intake, thus providing evidence of the beneficial potential of the training session methodology.

Such beneficial effects were not found in the M1 group suggesting that elaboration of optimal BFB methodology should be associated with assessment of ANS parameters. It should be mentioned that M2 migraine group was with decreased stress tolerance so ANS lability could be connected with PVA changes in a. temporalis and headache. Training for stabilizing PVA could decrease the pain severity and drug usage. PVA methodology is usable for stabilizing both branches of ANS however it might have had higher effect on PNS activity and that would be the reason of infectivity on M1 group, where PNS function was found already decreased. In the future the optimal training regimen for other migraine groups will be elaborated and larger patient groups will be studied, with the aim to evaluate the longitudinal effect of BFB training. 


\section{REFERENCES}

Anonymous (2004). Headache Classification Subcommittee of the International Headache Society. Classification of Headache Disorders. 2nd ed. Cephalalgia, 24(1), 1-150.

Agelink, M.W., Malessa, R., Baumann, B., Majewski, T., Akila, F., Zeit, T., Ziegler, D. (2001). Standardized tests of heart rate variability: Normal ranges obtained from 309 healthy humans, and effects of age, gender, and heart rate. Clin. Auton. Res., 11, 99-108.

Avnon, Y., Nitzan, M., Sprecher, E., Rogowski, Z., Yarnitsky, D. (2004). Autonomic asymmetry in migraine: Augmented parasympathetic activation in left unilateral migraineurs. Brain, 127, 2099-2108.

Benjelloun, H., Birouk, N., Slaoui, I., Coghlan, L., Oulad Amar Bencheikh, B., Jroundi, I., Benomar, M. (2005). Autonomic profile of patients with migraine. Clin. Neurophys., 35(4), 127-134.

Bertinieri, G., di Rienzo, M., Cavallazzi, A., Ferrari, A.U., Pedotti, A., Mancia, G. (1985). A new approach to analysis of the arterial baroreflex. $J$. Hypertens. Suppl., 3(suppl 3), S79-S81.

Blanchard, E.B., Kim, M. (2005). The effect of the definition of menstrually-related headache on the response to biofeedback treatment. Appl. Psychophysiol. Biofeedback, 30(1), 53-63.

Cortelli, P., Pierangeli, G., Parchi, P., Contin, M., Baruzzi, A., Lugaresi, E. (1991). Autonomic nervous system function in migraine without aura. Headache, 31(7), 457-462.

Gudmundsson, L.S., Thorgeirsson, G., Sigfusson, N., Sigvaldason, H., Johannsson, M. (2006). Migraine patients have lower systolic but higher diastolic blood pressure compared with controls in a population-based study of 21537 subjects. The Reykjavik Study. Cephalalgia, 26(4), $436-444$

Hermann, C., Blanchard, E.B. (2002). Biofeedback in the treatment of headache and other childhood pain. Appl. Psychophysiol. Biofeedback, 27(2), $143-162$

Kabbouche, M.A., Gilman, D.K. (2008). Management of migraine in adolescents. Neuropsychiatr. Dis. Treat., 4(3), 535-548.

Kardos, A., Watterich, G., de Menezes, R., Csanady, M., Casadei, B., Rudas, L. (2001). Determinants of spontaneous baroreflex sensitivity in a healthy working population. Hypertension, 37, 911-916.

Lipton, R.B., Bigal, M.E., Scheer, A.I., Steward, W.F. (2003). The global burden of migraine. J. Headache Pain, 4, 3-11.

Lipton, R.B., Stewart, W.F., Diamond, S., Diamond, M.L., Reed, M. (2001). Prevalence and burden of migraine in the United States: Data from the American Migraine Study II. Headache, 41, 646-657.

Lisspers, J., Ost, L.G. (1990). BVP-biofeedback in the treatment of migraine. The effects of constriction and dilatation during different phases of the migraine attack. Behav. Modif., 14(2), 200-221.

Mark, A.L., Victor, R.G., Nerhed, C., Wallin, B.G. (1985). Microneurograpfic studies of the mechanisms of sympathetic nerve responses to static exercise in humans. Circ. Res., 57, 461-469.

Martin, P.R., Forsyth, M.R., Reece, J. (2007). Cognitive - behavioral therapy versus temporal pulse amplitude biofeedback training for recurrent headache. Behav. Ther., 38, 350-363.
McGuire, B.E, Hogan, M.J, Morrison, T.G. (2008). Dimensionality and reliability assessment of the Pain Patient Profile Questionnaire. Eur. J. Psychol. Assess., 24(1), 22-26.

Mosek, A., Novak, V., Opfer-Gehrking, T.L., Swanson, J.W., Low, P.A (1999). Autonomic dysfunction in migraineurs. Headache, 39, 108-117.

Nestoriuc, Y., Martin, A., Ref, W., Andrasik, F. (2008). Biofeedback treatment for headache disorders: A comprehensive efficacy review. Appl. Psychophysiol. Biofeedback, 33, 125-140.

Nestoriuc, Y., Martin, A. (2007). Efficacy of biofeedbck for migraine: A meta-analysis. Pain, 128, 111-127.

Nilsen, K.B, Tronvik, E., Sand, T., Gravdahl, G.B., Stovner, L.J. (2009). Increased baroreflex sensitivity and heart rate variability in migraine patients. Acta Neurol. Scand., 120(6), 418-423.

Olesen, J. (2005). The Classification and Diagnosis of Headache Disorders. Oxford: Oxford University Press. 328 pp.

Osipova, V. (1992). Psychoautonomic approaches to migraine. Funct. Neurol., 7, 263-273.

Parati, G., Di Rienzo, M., Bertinieri, G., Pomidossi, G., Casadei, R., Groppelli, A., Pedotti, A., Zanchetti, A., Mancia, G. (1988). Evaluation of the baroreceptor-heart rate reflex by 24 -hour intra-arterial blood pressure monitoring in humans. Hypertension, 12, 214-222.

Peroutka, S.J. (2004). Migraine: A chronic sympathetic nervous system disorder. Headache, 44, 53-64.

Pierangeli, G., Parchi, P., Barletta, G., Chiogna, M., Lugaresi, E., Cortelli, P. (1997). Power spectral analysis of heart rate and diastolic blood pressure variability in migraine with and without aura. Cephalalgia, 17, 756-760.

Pogacnik, T., Sega, S., Pecnik, B., Kiauta, T. (1993). Autonomic function testing in patients with migraine. Headache, 33, 545-550.

Sanya, E.O., Brown, C.M., von Wilmowsky, C., Neundorfer, B., Hilz, M.J. (2005). Impairment of parasympathetic baroreflex responses in migraine patients. Acta Neurol. Scand., 111, 102-107.

Scharff, L., Marcus, D.A., Masek, B.J. (2002). A controlled study of minimal-contact thermal biofeedback treatment in children with migraine. $J$. Ped. Psychol., 27(2), 109-119.

Shechter, A., Stewart, W.F., Silberstein, S., Lipton, R. (2002). Migraine and autonomic nervous system function. A population-based, case-control study. Neurology, 58(3), 422-427.

Speckenbach, U., Gerber, W.D. (1999). Reliability of infrared plethysmography in BVP biofeedback therapy and the relevance for clinical application. Appl. Psychophysiol. Biofeedback, 24(4), 261-265.

Stovner, L.J., Zwart, J.A., Hagen, K., Terwindt, G.M., Pascual, J.P. (2006). Epidemiology of headache in Europe. Eur. J. Neurol., 13, 333-345.

Yakinci, C., Mungen, B., Er, H., Durmaz, Y., Karabiber, H. (1999). Autonomic nervous system function in childhood migraine. Pediatr. Int., 41, 529-533.

Yarnitsky, D., Goor-Aryeh, I., Bajwa, Z.H., Ransil, B.I., Cutrer, F.M., Sottile, A., Burstein, R. (2003). 2003 Wolff Award: Possible parasympathetic contributions to peripheral and central sensitization during migraine. Headache, 43, 704-714.

Received 23 March 2010

\section{AUTONOMĀS NERVU SISTĒMAS DARBĪBAS ĪPATNĪBAS MIGRĒNAS PACIENTIEM UN NEMEDIKAMENTOZA ĀRSTĒŠANA MIGRĒNAS LËKMJU STARPLAIKOS}

Pētījuma mērkis bija noteikt autonomās nervu sistēmas (ANS) darbības īpatnības migrēnas pacientiem un izstrādāt optimālas bioloğiskās atgriezeniskās saites (BAS) treninmetodes. Sirdsdarbības frekvence (SF), arteriālais asinsspiediens un barorefleksu jutība (BRJ) tika mērīta relatīvā fiziskā mierā, statiskā slodzēe, pēcdarba arteriālajā oklūzijā un atjaunošanās periodā. Pētījumā piedalījās 22 migrēnas pacienti (sievietes, vecums 22,2 $\pm 2,4$ gadi) un 14 pēc vecuma un dzimuma atbilstošas veselas kontroles grupas sievietes. Pēc SF un BRJ datiem mierā migrēnas pacienti tika iedalīti divās grupās (M1 un M2). Relatīva fiziska miera stāvoklī 60\% migrēnas pacientu (M1 grupa) tika konstatēta samazināta SF, salīdzinot ar kontroles grupu $(P<0,01)$. BRJ miera stāvoklī M2 grupai salīdzinot ar kontroles grupa un M1 grupu bija samazināta $(P<$ 0,01). 10 sekunžu pirmsslodzes periodā, kas tika saistīta ar orientācijas reakciju un mobilizāciju darbam, M1 grupā bija ievērojami mazāks SF pieaugums, salīdzinot ar citām analizētajām grupām $(P<0,01)$. Atjaunošanās periodā M1 grupai SF tika konstatēta ticami mazāka, nekā kontroles un M2 grupās $(P<0,05)$. Tika konstatēts, ka abas ANS daḷas - parasimpatiskā nervu sistēma (PNS) un simpātiskā nervu sistēma (SNS) ir izmainītas migrēnas slimniekiem. M2 grupā vērojama samazināta PNS aktivitāte un izmainīta SNS aktivitāte. M1 grupai ir palielināta PNS aktivitāte. BAS treniņi samazināja zāḷu lietošanu migrēnas lēkmēm un migrēnas lēkmju frekvenci M2 grupā, bet būtiski neietekmēja rezultātus M1 grupā. Tālāki pētījumi par nemedikamentozās modulācijas iespējām tiks veikti M1 grupā. 